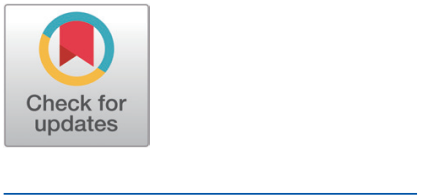

Received: Aug 5, 2020

Revised: Nov 27, 2020

Accepted: Dec 7, 2020

*Corresponding author

Koo Bok Chin

Department of Animal Science,

Chonnam National University, Gwangju

61186 , Korea

Tel: +82-62-530-2121

E-mail:kbchin@chonnam.ac.kr

Copyright (c) 2021 Korean Society of Animal Sciences and Technology.

This is an Open Access article distributed under the terms of the Creative Commons Attribution Non-Commercial License (http:// creativecommons.org/licenses/by$\mathrm{nc} / 4.0 /$ ) which permits unrestricted non-commercial use, distribution, and reproduction in any medium, provided the original work is properly cited.

ORCID

Geon Ho Kim

https://orcid.org/0000-0002-4700-4485 Koo Bok Chin

https://orcid.org/0000-0002-8062-6331

Competing interests

No potential conflict of interest relevant to this article was reported.

Funding sources

This work was supported by technology development program (\# PJ013809022018) for Rural

Development Administration, Korea.

Acknowledgements

This work was supported by technology development program

(\# PJ013809022018) for Rural

Development Administration, Korea.

\section{Characteristics of low-nitrite pork emulsified-sausages with paprika oleoresin solution during refrigerated storage}

\author{
Geon Ho Kim and Koo Bok Chin* \\ Department of Animal Science, Chonnam National University, Gwangju 61186, Korea
}

\begin{abstract}
The objective of this study was to evaluate quality characteristics of low-nitrite emulsified-sausages (ESs, $<75 \mathrm{ppm}$ ) containing paprika oleoresin solution (POS) for replacing sodium nitrite $\left(\mathrm{NaNO}_{2}\right)$. Pork ESs were prepared with four treatments (reference (REF), $150 \mathrm{ppm}$ $\mathrm{NaNO}_{2} ;$ TRT1, 0 ppm NaNO${ }_{2}+0.1 \%$ POS; TRT2, 37.5 ppm NaNO${ }_{2}+0.1 \%$ POS; and TRT3, $75 \mathrm{ppm} \mathrm{NaNO}+0.1 \%$ POS). The physicochemical and texture properties, microbial counts, residual nitrite and thiobarbituric acid reactant substances (TBARS) were measured during refrigerated storage of 35 days. Although TRT2 and TRT3 had lower levels of $\mathrm{NaNO}_{2}$, they had higher redness and yellowness than REF $(p<0.05)$. Microbial counts of total bacterial counts and Enterobacteriaceae of TRT2 and TRT3 were similar to those of REF ( $p>0.05)$. Expressible moisture percentages (EM, \%) of TRT2 and TRT3 were lower than those of REF $(p<0.05)$. TBARS values of TRT2 and TRT3 were not different from those of REF $(p>0.05)$. Among treatments, TRT1 had the highest TBARS values $(p<0.05)$. In conclusion, $0.1 \%$ POS in combination with $37.5 \mathrm{ppm} \mathrm{NaNO}$ would have quality characteristics similar to those of REF. Therefore, approximately $3 / 4$ of the initial nitrite level could be replaced with $0.1 \%$ POS, and eventually developed healthier pork products.
\end{abstract}

Keywords: Low-nitrite emulsified sausage, Paprika oleoresin solution, Quality characteristics

\section{INTRODUCTION}

Sodium nitrite $\left(\mathrm{NaNO}_{2}\right)$ is an essential curing ingredient for the manufacture of meat products, such as ham and sausages. When nitrite is added to the manufacture of meat products, it reacts with myoglobin in muscles, resulting in the formation of a pink color pigment, named nitrosohemochrome [1,2]. Because the color of meat products is one of important purchasing factors for consumers [3]. Nitrite is highly related to the commercial value of meat products. In addition, it also improves sensory characteristics by providing unique flavor to meat products $[4,5]$, and extend the shelf-life of meat products by inhibiting the growth of microorganisms and toxin production of Clostridium botulinum, which produced the toxin that causes food poisoning [6,7].

However, if excess $\mathrm{NaNO}_{2}$ was taken by eating foods containing nitroso compounds, $\mathrm{N}$-nitrosamine, a carcinogen, might be produced by combining $\mathrm{NaNO}_{2}$ and amino acids or secondary amines in 
Availability of data and material Upon reasonable request, the datasets of this study can be available from the corresponding author.

Authors' contributions Conceptualization: Kim GH, Chin KB. Data curation: Kim GH. Formal analysis: Kim GH, Chin KB. Investigation: Kim GH. Writing - original draft: Kim GH. Writing - review \& editing: Chin KB.

Ethics approval and consent to participate This article does not require IRB/IACUC approval because there are no human and animal participants. human's digestive system [8,9]. Furthermore, processed meats are classified as carcinogens by the World Health Organization (WHO) [10]. In general, consumers had limited knowledge about nitrite being added to meat products [11]. To satisfy consumers who want to eat healthier meat products and increase their preference for meat products, it is necessary to replace nitrite or reduce the level of nitrite by replacing the color development function and storage extension function of nitrite. For this purpose, studies have been conducted using red beet [12], anka rice [13], Opuntia ficus-indica pigment [14], and purple sweet potato powder [15].

Paprika (Capsicum annuum var. angulosum) is an annual plant of Solanaceae Capsicum and $A n$ muиm. It has considerable amounts of natural antioxidants, such as vitamin $\mathrm{C}$ and $\mathrm{E}$, tocopherol, and carotenoids [16]. In addition, it has been reported that capsanthin, a red pigment carotenoid in red paprika fruit, could enhance the redness of meat products [17]. Considering these findings, paprika might be suitable as a natural substance that can substitute and reduce the addition amount of nitrite because it can increase the redness of meat products and improve their shelf-life.

Paprika oleoresin is a lipophilic matrix that is produced by processing paprika fruit. It is mainly composed of glyceride, liposoluble polyphenolic antioxidants and carotenoid pigments and used as a colorant for meat-based meals in the food industries [18,19]. Paprika oleoresin has excellent coloring capacity because it is composed of high carotenoid concentration [18,20,21]. Therefore, it is enough to represent the coloring effect of paprika [22]. Considering the antioxidant effect and color stability of paprika oleoresin, the addition of that to the meat products might reduce or replace the content of $\mathrm{NaNO}_{2}$. However, there were not many studies regarding these topics. Therefore, the objective of this study was to evaluate quality characteristics, and storage properties of low-nitrite pork emulsified-sausage (ES) added with paprika oleoresin solution (POS) for the development of low-nitrite pork products.

\section{MATERIALS AND METHODS}

\section{Materials}

Raw meat and fat used in the experiment were from 1st grade castrated crossbreed (Landrace $\times$ Yorkshire). Back fat was purchased from a retail meat market (Hyundai Retail Meat Market, Gwangju, Korea). After removing connective tissues and external fat, raw hams were minced using meat chopper (M-12S, Korea Fuji Kogyo, Hwaseong, Korea), vacuum packaged, and stored frozen until utilized. Fat was cut off from the surface of the raw material, ground using a meat grinder, and stored at $-50^{\circ} \mathrm{C}$. Paprika oleoresin was obtained from Kalsec (Kalamazoo, MI, USA). Sunflower seed oil used to make POS was purchased from a local supermarket. Paprika oleoresin and sunflower seed oil were diluted to approximately 20 times $\left(\mathrm{pH} 3.43\right.$, CIE color value was $\mathrm{L}^{*}=52.1$, a* $=55.4, \mathrm{~b}^{*}=54.1$, main ingredient is lipid), respectively.

\section{Preparation of emulsified-sausages}

Detailed formulation for ESs is listed in Table 1. After raw meat was mixed with curing ingredients with ice water using a hood mixer (Mixer, HMC-401, Hanil Electric, Seoul, Korea), fat and POS were added and emulsified. The stuffed meat batter was heated in a constant temperature water bath (WB-22, Daihan Scientific, Seoul, Korea) at $75^{\circ} \mathrm{C}$ for $30 \mathrm{~min}$, cooled, and stored at $10^{\circ} \mathrm{C}$ until analyzed. Quality characteristics of ESs were measured on the $0,3,7,14,21,28$, and 35 days after preparation.

\section{$\mathrm{pH}$ and color measurements}

The $\mathrm{pH}$ values of sausages were determined using a Minolta Color Reader (CR-10, Minolta, To- 
Table 1. Formulation of pork emulsified-sausages with various content of sodium nitrite and paprika oleoresin solution

\begin{tabular}{lllll}
\hline \multirow{2}{*}{ Ingredients (\%) } & \multicolumn{5}{c}{ Treatment } \\
\cline { 2 - 5 } & REF & TRT1 & TRT2 & TRT3 \\
\hline Raw pork meat & 60.0 & 60.0 & 60.0 & 60.0 \\
Fat & 20.0 & 20.0 & 20.0 & 20.0 \\
Water & 18.0 & 18.0 & 18.0 & 18.0 \\
Non meat ingredients & & & & \\
$\quad$ Salt & 1.50 & 1.50 & 1.50 & 1.50 \\
Sodium tripolyphosphate & 0.40 & 0.40 & 0.40 & 0.40 \\
$\quad$ Sodium erythorbate & 0.05 & 0.05 & 0.05 & 0.05 \\
$\quad$ Sodium nitrite & 0.015 & 0.00 & 0.00375 & 0.0075 \\
$\quad$ Paprika oleoresin solution & & & & \\
$\quad$ Oleoresin paprika & 0.00 & 0.005 & 0.005 & 0.005 \\
$\quad$ Sunflower seed oil & 0.00 & 0.095 & 0.095 & 0.095 \\
\hline \multicolumn{1}{c}{ Total } & 100.0 & 100.0 & 100.1 & 100.1 \\
\hline
\end{tabular}

REF, reference (150 ppm sodium nitrite); TRT1, treatment 1 (0 ppm sodium nitrite, $0.1 \%$ paprika oleoresin solution), TRT2, treatment 2 (37.5 ppm sodium nitrite, 0.1\% paprika oleoresin solution); TRT3, treatment 3 (75 ppm sodium nitrite, $0.1 \%$ paprika oleoresin solution).

kyo, Japan). Measurements for $\mathrm{pH}$ were performed 5 times per sample, and the means of the values were calculated.

The color values were measured by CIE L*, CIE a*, and CIE b * using a Minolta Color Reader (CR-10, Minolta, Osaka, Japan). After color values were measured six times, results were averaged for these six measurements (CIE color value of the standard white plate was $L^{*}=94.8, a^{*}=1.0, b^{*}=$ $0.1)$.

\section{Proximate composition}

Proximate composition was determined according to the AOAC [23]. Moisture content (\%) was determined with the dry oven method. Fat content (\%) was determined with the Soxhlet extraction method and the protein content (\%) was determined with the Kjeldahl method.

\section{Cooking loss (CL)}

CL (\%) was measured based on the weight of sausage before and after heating. It was calculated by substituting the following formula.

$$
\text { Cookingloss }(\%)=\frac{\text { Sample weight }(\mathrm{g})(\text { before cooking }- \text { after cooking })}{\text { Sample weight before heating }(\mathrm{g})} \times 100
$$

\section{Texture profile analysis}

Samples were prepared by setting a shape of $1.25 \mathrm{~cm}$ in diameter and $1.3 \mathrm{~cm}$ in height. Hardness (gf), springiness (mm), gumminess, chewiness, and cohesiveness of each sample were measured ten times with an Instron Universal Machine (Model 3344, Instron, Canton, MA, USA).

\section{Microbiological analysis}

Microbial counts were performed by mixing $10 \mathrm{~g}$ of homogenized sausage samples with $90 \mathrm{~mL}$ of sterile distilled water and diluting them to in appropriate proportion. Total plate count (TPC) and violet red bile (VRB) agar were used for the determination of a total number of bacteria 
and Enterobacteriaceae, respectively. After applying diluted samples onto agar plates, plates were incubated for $48 \mathrm{hrs}$ at $37^{\circ} \mathrm{C}$. Results are expressed as $\log \mathrm{CFU} / \mathrm{g}$.

\section{Expressible moisture (EM)}

EM (\%) was prepared by cutting the sausage into a rectangular parallelepiped shape of about 1.5 g. The sample was wrapped in three equal pieces of Whatman \#3 filter paper, placed into a conical tube, and centrifuged at 1,660×g (VS-5500, Vision Science, Gyeongsan, Korea) for $15 \mathrm{~min}$. The amount of water liberated from the sample in the filter paper was then measured and substituted into the following formula.

$$
\text { Expressible moisture }(\%)=\frac{\text { Expressible water weight of filter paper }(\mathrm{g})}{\text { Sample weight }(\mathrm{g})} \times 100
$$

\section{Residual nitrite}

Residual nitrite level (ppm) was determined by modifying the method of AOAC [23]. Briefly, approximately $5 \mathrm{~g}$ of ground sausage sample was mixed with $300 \mathrm{~mL}$ of distilled water and heated for $1 \mathrm{hr}$ in a constant temperature water bath (WB-22, Daihan Scientific) at $100^{\circ} \mathrm{C}$. After filtration, the sample was diluted with distilled water to make a mixture of $500 \mathrm{~mL}$. Approximately $2.5 \mathrm{~mL}$ of sulfanilamide solution was added to $25 \mathrm{~mL}$ of this mixture, vortexed, and allowed to react at room temperature for about $5 \mathrm{~min}$. Then, $2.5 \mathrm{~mL}$ of $\mathrm{N}$-(1-Naphthyl) ethylene dihydrochloride solution was added to $25 \mathrm{~mL}$ of this mixture, vortexed, and allowed to react at room temperature for about 5 min. The absorbance was measured using a spectrophotometer (Model UV-1601, Shimadzu, Kyoto, Japan) at a wavelength of $540 \mathrm{~nm}$. The measured absorbance was assigned to a standard curve obtained by measuring the absorbance of nitrite solution to derive the residual amount of nitrite.

\section{Thiobarbituric acid substances (TBARS)}

TBARS was measured using the method of Sinnhuber and $\mathrm{Yu}$ [24]. Briefly, $2 \mathrm{~g}$ of ground sausage sample, $3 \mathrm{~mL}$ of thiobarbituric acid, and $17 \mathrm{~mL}$ of trichloroacetic acid $(100 \mathrm{mg} / \mathrm{mL})$ were mixed by vortexing, homogenized, and heated in a water bath (WB-22, Daihan Scientific) at $100^{\circ} \mathrm{C}$ for $30 \mathrm{~min}$. After heating, samples were cooled at room temperature, then $5 \mathrm{~mL}$ of the supernatant of the sample and $5 \mathrm{~mL}$ of chloroform were vortexed together for $1 \mathrm{~min}$, mixed, and centrifuged at 3,000 rpm (Model VS-5500, Vision Science) for about $5 \mathrm{~min}$. Then, $3 \mathrm{~mL}$ of the supernatant of the sample was mixed with $3 \mathrm{~mL}$ of petroleum ether for $1 \mathrm{~min}$ by vortexing. The mixture was then centrifuged at 3,000 rpm for $10 \mathrm{~min}$. The absorbance of the reaction product was measured using a spectrophotometer (Model UV-1601, Shimadzu) at a wavelength of $532 \mathrm{~nm}$. The TBARS value was calculated by substituting the measured absorbance into the following equation.

$$
\text { TBARS value }\left(\mathrm{mg} \text { of MDA } / \mathrm{kg} \text { of sample) }=\frac{\text { O.D. value } \times 9.48}{\text { Sample weight }(\mathrm{kg})}\right.
$$

\section{Statistical analysis}

The whole experiments were performed in triplicate. The mean and standard deviation of the mean were calculated using IBM SPSS Statistics 23 (SPSS, Chicago, IL, USA). This experiment was carried out with two-way ANOVA (treatments $\times$ storage time). If the interaction between two factors were observed $(p<0.05)$, then the data were separated by treatments within the storage time or storage time within the treatments. If no interaction between two factors were observed $(p>0.05)$, then the data were pooled by treatments or storage time. Post ANOVA was performed by Duncan's 
multiple range test at significance level of 0.05 .

\section{RESULTS AND DISCUSSION}

\section{$\mathrm{pH}$ and color measurement}

Since results of $\mathrm{pH}$ and color had no interaction between the treatment and storage time, data were pooled by treatment in a storage time and storage time in a treatment. Results of $\mathrm{pH}$ among all treatments and storage time were not different (Table 2). As shown in Table 2, $\mathrm{L}^{*}$ values of TRT1 were the highest among all treatments $(p<0.05)$, while those of other treatments were similar $(p$ $>0.05)$. Measured $\mathrm{a}^{*}$ values were higher in the order of TRT3 $>$ TRT2 $>$ REF $>$ TRT1 $(p<0.05)$. Although lower levels of $\mathrm{NaNO}_{2}$ were added into TRT2 and TRT3 compared to the level added to REF (150 ppm $\mathrm{NaNO}_{2}$ ), a* values of TRT2 and TRT3 were higher than those of REF due to the additional effect of POS, whereas $b^{*}$ values were highest in TRT1 and lowest in REF. The addition of POS increased the yellowness which indicated that POS might increase both $\mathrm{a}^{*}$ and $\mathrm{b}^{*}$ values. In a previous study, when approximately $1 \%$ paprika oleoresin was added to the oil for marinating chicken breast, $a^{*}$ and $b^{*}$ values of treatments containing POS were increased by 0.87 and 3.82, respectively [26]. This is because carotenoid, a red and yellow pigment, present in paprika oleoresin. $L^{*}, a^{*}$, and $b^{*}$ values of all treatments did not show significant change during refrigerated storage $(p$ $>0.05$ ).

\section{Proximate composition}

There were no significant differences in water, fat, or protein contents (\%) among all treatments ( $p$ > 0.05 ), the addition of POS did not significantly affect proximate compositions of ESs (data are not shown). This result might be due to the lower level (0.1\%) of POS added into the sausage. According to Yusop et al. [19], even though the contents of paprika oleoresin was increased up to 3 times, the marinated chicken breast prepared with paprika oleoresin didn't change in moisture and fat contents (\%).

Table 2. The $\mathrm{pH}$ and color values of emulsified-sausages with various content of sodium nitrite and paprika oleoresin solution

\begin{tabular}{|c|c|c|c|c|}
\hline & $\mathrm{pH}$ & $\mathrm{CIE} \mathrm{L*}^{*}$ & $\mathrm{CIE} \mathrm{a}^{*}$ & $\mathrm{CIE} b^{*}$ \\
\hline \multicolumn{5}{|c|}{ Treatment } \\
\hline REF & $6.06 \pm 0.07^{\mathrm{a}}$ & $73.6 \pm 0.73^{b}$ & $10.7 \pm 0.53^{c}$ & $6.19 \pm 0.74^{d}$ \\
\hline TRT1 & $6.05 \pm 0.09^{\mathrm{a}}$ & $74.9 \pm 1.04^{\mathrm{a}}$ & $6.60 \pm 0.46^{d}$ & $9.62 \pm 0.56^{a}$ \\
\hline TRT2 & $6.08 \pm 0.08^{\mathrm{a}}$ & $73.9 \pm 1.37^{b}$ & $11.7 \pm 0.57^{\mathrm{b}}$ & $7.51 \pm 0.20^{c}$ \\
\hline TRT3 & $6.08 \pm 0.08^{a}$ & $73.2 \pm 0.89^{b}$ & $12.3 \pm 0.58^{\mathrm{a}}$ & $7.86 \pm 0.32^{b}$ \\
\hline \multicolumn{5}{|c|}{ Storage time $(\mathrm{d})$} \\
\hline 0 & $6.08 \pm 0.08^{a}$ & $73.8 \pm 1.04^{\mathrm{a}}$ & $10.5 \pm 2.18^{\mathrm{a}}$ & $7.74 \pm 1.56^{a}$ \\
\hline 3 & $6.11 \pm 0.09^{a}$ & $73.9 \pm 1.36^{\mathrm{a}}$ & $10.2 \pm 2.42^{\mathrm{a}}$ & $7.80 \pm 1.48^{\mathrm{a}}$ \\
\hline 7 & $6.10 \pm 0.08^{a}$ & $73.9 \pm 1.36^{\mathrm{a}}$ & $10.3 \pm 2.57^{\mathrm{a}}$ & $7.79 \pm 1.55^{\mathrm{a}}$ \\
\hline 14 & $6.05 \pm 0.12^{\mathrm{a}}$ & $74.1 \pm 1.06^{\mathrm{a}}$ & $10.4 \pm 2.39^{\mathrm{a}}$ & $7.87 \pm 1.40^{\mathrm{a}}$ \\
\hline 21 & $6.03 \pm 0.06^{a}$ & $73.8 \pm 1.28^{\mathrm{a}}$ & $10.3 \pm 2.34^{a}$ & $7.72 \pm 1.25^{\mathrm{a}}$ \\
\hline 28 & $6.06 \pm 0.06^{a}$ & $73.9 \pm 1.12^{\mathrm{a}}$ & $10.3 \pm 2.32^{\mathrm{a}}$ & $7.95 \pm 1.10^{\mathrm{a}}$ \\
\hline 35 & $6.05 \pm 0.06^{\mathrm{a}}$ & $74.1 \pm 1.41^{\mathrm{a}}$ & $10.3 \pm 2.44^{a}$ & $7.69 \pm 1.21^{\mathrm{a}}$ \\
\hline
\end{tabular}

${ }^{a-d}$ Mean having same superscripts in a same column are not different $(p>0.05)$.

REF, reference (150 ppm sodium nitrite); TRT1, treatment 1 ( 0 ppm sodium nitrite, $0.1 \%$ paprika oleoresin solution), TRT2, treatment 2 ( $37.5 \mathrm{ppm}$ sodium nitrite, $0.1 \%$ paprika oleoresin solution); TRT3, treatment 3 ( $75 \mathrm{ppm}$ sodium nitrite, $0.1 \%$ paprika oleoresin solution). 


\section{Cooking loss}

As shown in Table 3, CL (\%) were not significantly different among treatments $(p>0.05)$. It indicated that different additional levels of $\mathrm{NaNO}_{2}$ and POS had no effect on CL of ESs. Kim and Chin [27] reported that CL of pork sausage with paprika powder were similar to those of control without paprika powder.

\section{Texture profile analysis}

The addition of POS did not affect the textural properties such as hardness, springiness, gumminess, chewiness, or cohesiveness ( $p>0.05$ ) (Table 3). In a previous study, Bázan-Lugo et al. [17] evaluated quality characteristics of sausages added with or without $1.5 \%$ of paprika powder, and reported that the similar hardness and springiness were measured, regardless of the addition of paprika powder. Revilla and Quintana [28] also reported that the addition of paprika did not affect the textural properties of chorizo type of sausage $(p>0.05)$. Based on these results, the paprika powder might not affect the textural properties of the meat products.

\section{Microbiological analysis}

Table 4 shows microbiological counts of pork emulsion type sausages added with POS. Total microbial counts (TPC) of TRT1 were higher than those of other treatments $(p<0.05)$. This probably due to the absence of $\mathrm{NaNO}_{2}$, which might have antimicrobial activity against many microbial species including Pseudomonas aeruginosa [29]. TRT2 and TRT3 showed similar total microbial counts to REF, indicating that addition of POS might have the antimicrobial activity. De Oliveira et al. [30] inoculated Clostridium perfringens into mortadella-type sausages added with 0,100, and $200 \mathrm{ppm}$ of $\mathrm{NaNO}_{2}$, respectively, and they found that the higher the $\mathrm{NaNO}_{2}$ content, the lower the number of microorganisms. The addition of $200 \mathrm{ppm}$ of $\mathrm{NaNO}_{2}$ into the sausage was lower than those with $100 \mathrm{ppm}$ after 30 days of storage $(p<0.05)$. This means that higher ingoing level of nitrite could retard microbial growth more quicky. Microbial counts of Enterobacteriaceae higher than $10^{2} \mathrm{CFU} / \mathrm{g}$ were detected in TRT1. However, they were not detected in REF, TRT2, or TRT3. Carotenoids present in paprika could inhibit the growth of microorganisms such as Bacillus subtilis, Staphylococcus aureus, Escherichia coli, Aspergillus niger, Aspergillus flavus, Penicillium chrysogenum, Rbizopus oryzae, and Saccharomyces [29]. Paprika extracts including paprika oleoresin can destroy microorganisms in the biofilm [31]. Therefore, the addition of POS seems to reduce total bacterial counts and the microbial counts of Enterobacteriaceae counts. In this study, total bacterial counts

Table 3. The cooking loss and texture profile analysis of pork emulsified-sausages with content of sodium nitrite and paprika oleoresin solution

\begin{tabular}{lcccc}
\hline & \multicolumn{4}{c}{ Treatment } \\
\cline { 2 - 5 } & REF & TRT1 & TRT2 & TRT3 \\
\hline Cooking loss (\%) & $2.05 \pm 1.53^{\mathrm{a}}$ & $1.73 \pm 0.37^{\mathrm{a}}$ & $1.35 \pm 0.15^{\mathrm{a}}$ & $1.32 \pm 0.69^{\mathrm{a}}$ \\
Hardness (gf) & $3,688 \pm 381^{\mathrm{a}}$ & $3,226 \pm 418^{\mathrm{a}}$ & $3,529 \pm 339^{\mathrm{a}}$ & $3,650 \pm 380^{\mathrm{a}}$ \\
Springiness (mm) & $4.32 \pm 0.40^{\mathrm{a}}$ & $4.42 \pm 0.19^{\mathrm{a}}$ & $4.42 \pm 0.16^{\mathrm{a}}$ & $4.48 \pm 0.34^{\mathrm{a}}$ \\
Gumminess & $36.2 \pm 1.43^{\mathrm{a}}$ & $36.8 \pm 2.03^{\mathrm{a}}$ & $36.6 \pm 2.50^{\mathrm{a}}$ & $35.9 \pm 3.79^{\mathrm{a}}$ \\
Chewiness & $154 \pm 2.24^{\mathrm{a}}$ & $157 \pm 4.70^{\mathrm{a}}$ & $154 \pm 1.84^{\mathrm{a}}$ & $154 \pm 3.31^{\mathrm{a}}$ \\
Cohesiveness & $0.01 \pm 0.00^{\mathrm{a}}$ & $0.01 \pm 0.00^{\mathrm{a}}$ & $0.01 \pm 0.00^{\mathrm{a}}$ & $0.01 \pm 0.00^{\mathrm{a}}$ \\
\hline
\end{tabular}

REF, reference (150 ppm sodium nitrite); TRT1, treatment 1 (0 ppm sodium nitrite, $0.1 \%$ paprika oleoresin solution), TRT2, treatment 2 (37.5 ppm sodium nitrite, $0.1 \%$ paprika oleoresin solution); TRT3, treatment 3 ( 75 ppm sodium nitrite, $0.1 \%$ paprika oleoresin solution).

${ }^{a}$ Mean having same superscripts in a same row are not different $(p>0.05)$. 
Table 4. The microbiological counts (Log CFU/g) and expressible moisture (\%) of pork emulsifiedsausages with content of sodium nitrite and paprika oleoresin solution

\begin{tabular}{lccc}
\hline & TPC & VRB & EM \\
\hline Treatment & & & \\
REF & $2.04 \pm 2.03^{\mathrm{b}}$ & $<2.00^{\mathrm{b}}$ & $18.8 \pm 0.76^{\mathrm{b}}$ \\
TRT1 & $2.72 \pm 2.05^{\mathrm{a}}$ & $2.05 \pm 1.97^{\mathrm{a}}$ & $19.0 \pm 1.07^{\mathrm{a}}$ \\
TRT2 & $2.19 \pm 2.03^{\mathrm{b}}$ & $<2.00^{\mathrm{b}}$ & $18.5 \pm 0.89^{\mathrm{c}}$ \\
TRT3 & $2.03 \pm 2.04^{\mathrm{b}}$ & $<2.00^{\mathrm{b}}$ & $18.5 \pm 0.84^{\mathrm{c}}$ \\
Storage time (d) & & & \\
0 & $<2.00^{\mathrm{d}}$ & $<2.00^{\mathrm{d}}$ & $17.7 \pm 0.18^{\mathrm{f}}$ \\
3 & $<2.00^{\mathrm{d}}$ & $<2.00^{\mathrm{d}}$ & $18.0 \pm 0.39^{\mathrm{e}}$ \\
7 & $<2.00^{\mathrm{d}}$ & $<2.00^{\mathrm{d}}$ & $18.0 \pm 0.33^{\mathrm{e}}$ \\
14 & $2.30 \pm 1.40^{\mathrm{c}}$ & $<2.00^{\mathrm{d}}$ & $18.5 \pm 0.37^{\mathrm{d}}$ \\
21 & $3.90 \pm 0.24^{\mathrm{b}}$ & $3.31 \pm 0.32^{\mathrm{c}}$ & $19.2 \pm 0.42^{\mathrm{c}}$ \\
28 & $4.31 \pm 0.27^{\mathrm{ab}}$ & $3.78 \pm 0.37^{\mathrm{b}}$ & $15.5 \pm 0.38^{\mathrm{b}}$ \\
35 & $4.61 \pm 0.32^{\mathrm{a}}$ & $4.17 \pm 0.48^{\mathrm{a}}$ & $20.1 \pm 0.39^{\mathrm{a}}$ \\
\hline
\end{tabular}

${ }^{\mathrm{a}-f}$ Mean having same superscripts in a same column are not different $(p>0.05)$.

REF, reference (150 ppm sodium nitrite); TRT1, treatment 1 (0 ppm sodium nitrite, $0.1 \%$ paprika oleoresin solution), TRT2, treatment 2 (37.5 ppm sodium nitrite, 0.1\% paprika oleoresin solution); TRT3, treatment 3 (75 ppm sodium nitrite, $0.1 \%$ paprika oleoresin solution).

TPC, total plate counts; VRB, violet red agar; EM, expressible moisture.

were detected at more than $10^{2} \mathrm{CFU} / \mathrm{g}$ from 14 days, and the microbial counts of Enterobacteriaceae counts were detected at more than $10^{2} \mathrm{CFU} / \mathrm{g}$ from 21 days.

\section{Expressible moisture}

As shown in Table 4, EM (\%) of TRT1 were the highest among all treatments $(p<0.05)$. These results might be partially due to the lowest water holding capacity of sausage without $\mathrm{NaNO}_{2}$. Thus, $\mathrm{NaNO}_{2}$ might be combined with other curing agents to improve water holding capacity in meat products [32]. On the other hand, EMs of TRT1 and TRT2 were lower than those of REF ( $p<$ $0.05)$.

\section{Residual nitrite (RN)}

Table 5 shows results of RN (ppm) of pork ESs with POS during refrigerated storage. Since RN was an interaction between treatment and storage day $(p<0.05)$, data were separated out by treatment in a storage time and storage time in a treatment. Amounts of $\mathrm{RN}$ decreased gradually with increased storage time $(p<0.05)$. RN levels of TRT2 on 0 and 3 days were similar $(p>0.05)$. All subsequent values were different from each other on each measurement day $(p<0.05)$. Since TRT1 did not contain $\mathrm{NaNO}_{2}$, no RN was present during the storage period, and its $\mathrm{RN}$ levels were lower than those in other treatments $(p<0.05)$. Roberts [33] determined the microbiological role of nitrates and nitrites using bacon, and reported that higher $\mathrm{RN}$ tends to be higher antimicrobial activity. According to this result, REF is expected to have long-term antimicrobial activity. Even though the residual amount was lower at 35 days, TRT2 and TRT3 didn't differ from REF in terms of microbial counts. These results might be due to the influence of POS. As shown in Table 5, RN levels of ESs were proportional to added levels of $\mathrm{NaNO}_{2}$. Thus, $\mathrm{RN}$ levels of $\mathrm{ESs}$ at 35 days of storage were significantly influenced by the amount of $\mathrm{NaNO}_{2}$ added. If the $\mathrm{RN}$ level is low (< $20 \mathrm{ppm}$ ), the possibility of producing N-nitrosamine also tends to be lower. Ahn et al. [34] reported that higher volatile N-nitrosamine levels (199 ppb) detected in pork sausage with higher RN level 
Table 5. The residual nitrite (ppm) of pork emulsified-sausages with content of sodium nitrite and paprika oleoresin solution

\begin{tabular}{lccccccc}
\hline \multirow{2}{*}{ Treatments } & \multicolumn{7}{c}{ Storage time (d) } \\
\cline { 2 - 7 } & $\mathbf{0}$ & $\mathbf{3}$ & $\mathbf{7}$ & $\mathbf{1 4}$ & $\mathbf{2 1}$ & $\mathbf{2 8}$ \\
\hline REF & $21.2 \pm 1.03^{\mathrm{Aa}}$ & $17.8 \pm 0.17^{\mathrm{Ab}}$ & $14.9 \pm 0.26^{\mathrm{Ac}}$ & $9.64 \pm 0.22^{\mathrm{Ad}}$ & $8.68 \pm 0.07^{\mathrm{Ae}}$ & $6.78 \pm 0.07^{\mathrm{Af}}$ & $4.88 \pm 0.09^{\mathrm{Ag}}$ \\
TRT1 & $\mathrm{ND}$ & $\mathrm{ND}$ & $\mathrm{ND}$ & $\mathrm{ND}$ & $\mathrm{ND}$ & $\mathrm{ND}$ & $\mathrm{ND}$ \\
TRT2 & $6.90 \pm 0.23^{\mathrm{Ca}}$ & $5.45 \pm 1.26^{\mathrm{Cab}}$ & $4.16 \pm 0.34^{\mathrm{Cb}}$ & $3.01 \pm 0.65^{\mathrm{Cc}}$ & $1.69 \pm 0.34^{\mathrm{Cd}}$ & $0.83 \pm 0.22^{\mathrm{Ce}}$ & $0.55 \pm 0.03^{\mathrm{Cf}}$ \\
TRT3 & $9.45 \pm 0.11^{\mathrm{Ba}}$ & $8.95 \pm 0.06^{\mathrm{Bb}}$ & $7.18 \pm 0.09^{\mathrm{Bc}}$ & $5.58 \pm 1.45^{\mathrm{Bd}}$ & $4.17 \pm 0.14^{\mathrm{Be}}$ & $2.87 \pm 0.28^{\mathrm{Bf}}$ & $1.91 \pm 1.14^{\mathrm{Bg}}$ \\
\hline
\end{tabular}

REF, reference (150 ppm sodium nitrite); TRT1, treatment 1 ( 0 ppm sodium nitrite, $0.1 \%$ paprika oleoresin solution), TRT2, treatment 2 ( 37.5 ppm sodium nitrite, $0.1 \%$ paprika oleoresin solution); TRT3, treatment 3 (75 ppm sodium nitrite, $0.1 \%$ paprika oleoresin solution).

${ }^{A-C}$ Mean having same superscripts in a same column are not different $(p>0.05)$.

${ }^{a-d}$ Mean having same superscripts in a same row are not different $(p>0.05)$.

ND, not detected

(104 ppm), whereas those with lower volatile N-nitrosamine levels (81.8 ppm) had lower volatile $\mathrm{N}$-nitrosamine levels (28.8 ppb).

\section{Thiobarbituric acid reactant substances (TBARS)}

Fig. 1 shows the results of measured TBARS of pork ESs during storage days. There were no significant differences in TBARS values among REF,TRT2, and TRT3 during storage periods from day 0 to 35 days $(p>0.05)$. TBARS values of TRT1 increased rapidly from 0 to 3 days, while those of other treatments, including REF increased slightly during the storage time. REF and TRT2 showed no changes in TBARS value from 21 days to the end of storage $(p>0.05)$. However, TRT2 and TRT3 did not change in TBARS values from 14 days to the end of the measurement $(p>$ 0.05). It is known that nitrite has ability to effectively delay the oxidation of cured meat [7]. In this study, TBARS values of TRT1 were the highest among all treatments. however, those of TRT2 and TRT3 added with nitrite at $37.5 \mathrm{ppm}$ and $75 \mathrm{ppm}$, respectively, and treatments with POS were

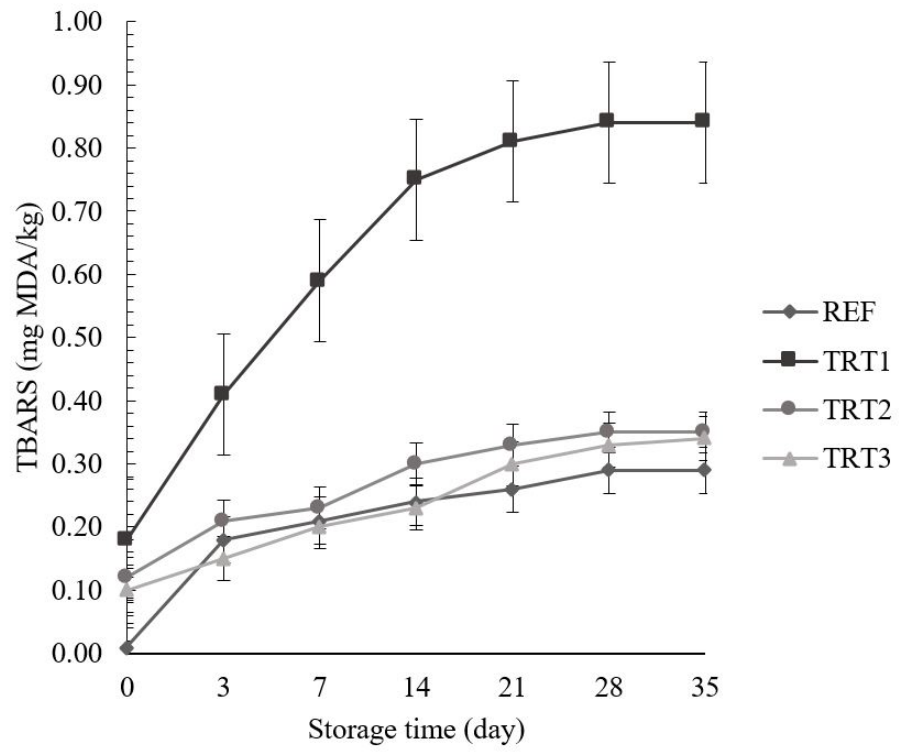

Fig. 1. The changes of thiobarbituric acid reactive substances of pork with content of sodium nitrite and paprika oleoresin solution. REF, reference (150 ppm sodium nitrite); TRT1, treatment 1 (0 ppm sodium nitrite, $0.1 \%$ paprika oleoresin solution), TRT2, treatment 2 (37.5 ppm sodium nitrite, $0.1 \%$ paprika oleoresin solution); TRT3, treatment 3 (75 ppm sodium nitrite, $0.1 \%$ paprika oleoresin solution). 
not different from those of REF ( $p>0.05$ ). Kim et al. [35] reported that $0.32 \%$ of oleoresin paprika added to pork patties could effectively inhibit lipid oxidation to replace $\mathrm{NaNO}_{2}$. This suggests that TRT2 and TRT3 might have similar levels of lipid oxidation, although added levels of nitrite were lower than the level added to REF. These results also suggest that POS might have antioxidant activity in meat products.

\section{CONCLUSION}

The addition of $0.1 \%$ POS increased the redness and yellowness of the pork ESs. Microbial counts and lipid oxidation of ESs added with 37.5 or $75 \mathrm{ppm} \mathrm{NaNO}_{2}$ and $0.1 \%$ POS were similar to those of ESs added with $150 \mathrm{ppm} \mathrm{NaNO}_{2}$. As a result, ESs added with $0.1 \% \mathrm{POS}$ and $37.5 \mathrm{ppm} \mathrm{NaNO}_{2}$ are similar quality characteristics to REF. Therefore, approximately $3 / 4$ of ingoing level of $\mathrm{NaNO}_{2}$ could be replaced with $0.1 \%$ POS in the manufacture of regular-fat sausage.

\section{REFERENCES}

1. Pearson AM, Gillett TA. Processed meats. 3rd ed. Berlin: Springer; 1996.

2. Munekata PES, Gullón B, Pateiro M, Tomasevic I, Domínguez R, Lorenzo JM. Natural antioxidants from seeds and their application in meat products. Antioxidants. 2020;9:815. https:// doi.org/10.3390/antiox9090815

3. Resurreccion AVA. Sensory aspects of consumer choices for meat and meat products. Meat Sci. 2004;66:11-20. https://doi.org/10.1016/S0309-1740(03)00021-4

4. Noel P, Briand E, Dumont JP. Role of nitrite in flavor development in uncooked cured meat products: sensory assessment. Meat Sci. 1990;28:1-8. https://doi.org/10.1016/03091740(90)90015-X

5. Sindelar JJ, Milkowski AL. Sodium nitrite in processed meat and poultry meats: a review of curing and examining the risk/benefit of its use. Kearney, MO: American Meat Science Association; 2011. AMSA White Paper Series No. 3.

6. Christiansen LN, Johnston RW, Kautter DA, Howard JW, Aunan WJ. Effect of nitrite and nitrate on toxin production by Clostridium botulinum and on nitrosamine formation in perishable canned comminuted cured meat. Appl Microbiol. 1973;25:357-62. https://doi. org/10.1128/AM.25.3.357-362.1973

7. Sindelar JJ, Milkowski AL. Human safety controversies surrounding nitrate and nitrite in the diet. Nitric Oxide. 2012;26:259-66. https://doi.org/10.1016/j.niox.2012.03.011

8. Ashworth IW, Dirat O, Teasdale A, Whiting M. Potential for the formation of N-nitrosamines during the manufacture of active pharmaceutical ingredients: an assessment of the risk posed by trace nitrite in water. Org Process Res Dev. 2020;24:1629-46. https://doi.org/10.1021/acs. oprd.0c00224

9. Hawksworth GM, Hill MJ. Bacteria and the N-nitrosation of secondary amines. Br J Cancer. 1971;25:520-6. https://doi.org/10.1038/bjc.1971.66

10. Simon S. World Health Organization says processed meat causes cancer [Internet]. American Cancer Society. 2015 [cited 2020 Oct 1]. https://www.dartmouth.edu/wellness/november_ archive.pdf

11. Hung Y, de Kok TM, Verbeke W. Consumer attitude and purchase intention towards processed meat products with natural compounds and a reduced level of nitrite. Meat Sci. 2016;121:119-26. https://doi.org/10.1016/j.meatsci.2016.06.002

12. Jeong HJ, Lee HC, Chin KB. Effect of red beet on quality and color stability of low-fat sausag- 
es during refrigerated storage. Korean J Food Sci Anim Resour. 2010;30:1014-23. https://doi. org/10.5851/kosfa.2010.30.6.1014

13. Liu DC, Wu SW, Tan FJ. Effects of addition of anka rice on the qualities of low-nitrite Chinese sausages. Food Chem. 2010;118:245-50. https://doi.org/10.1016/j.foodchem.2009.04.114

14. Kang JO, Lee SG. Effects of opuntia ficus-indica pigment and sodium lactate on nitrite-reduced sausages. J Anim Sci Technol. 2008;50:551-60. https://doi.org/10.5187/ JAST.2008.50.4.551

15. Lee N, Kim CS, Yu GS, Park MC, Jung WO, Jung UK, et al. Effect of nitrite substitution of sausage with addition of purple sweet potato powder and purple sweet potato pigment. J Korean Soc Food Sci Nutr. 2015;44:896-903. https://doi.org/10.3746/jkfn.2015.44.6.896

16. Daood HG, Kapitány J, Biacs P, Albrecht K. Drying temperature, endogenous antioxidants and capsaicinoids affect carotenoid stability in paprika (red pepper spice). J Sci Food Agric. 2006;86:2450-7. https://doi.org/10.1002/jsfa.2639

17. Bázan-Lugo E, García-Martínez I, Alfaro-Rodríguez RH, Totosaus A. Color compensation in nitrite-reduced meat batters incorporating paprika or tomato paste. J Sci Food Agric. 2012;92:1627-32. https://doi.org/10.1002/jsfa.4748

18. Rascón MP, Beristain CI, García HS, Salgado MA. Carotenoid retention and storage stability of spray-dried encapsulated paprika oleoresin using gum Arabic and soy protein isolate as wall materials. LWT-Food Sci Technol. 2011;44:549-57. https://doi.org/10.1016/j.lwt.2010.08.021

19. Yusop SM, O'Sullivan MG, Preuß M, Weber H, Kerry JF, Kerry JP. Assessment of nanoparticle paprika oleoresin on marinating performance and sensory acceptance of poultry meat. LWT-Food Sci Technol. 2012;46:349-55. https://doi.org/10.1016/j.lwt.2011.08.014

20. Jarén-Galán M, Pérez-Gálvez A, Mínguez-Mosquera MI. Prediction of decoloration in paprika oleoresins. Application to studies of stability in thermodynamically compensated systems. J Agric Food Chem. 1999;47:945-51. https://doi.org/10.1021/j99807972

21. Lu Q, Sun J, Huang M, GuoY, Memon A. Effect of storage temperatures and duration on quality of prepared chicken breast with paprika oleoresin. Anim Sci J. 2019;90:280-7. https:// doi.org/10.1111/asj.13117

22. Pérez-Gálvez A, Martin HD, Sies H, Stahl W. Incorporation of carotenoids from paprika oleoresin into human chylomicrons. Brit J Nutr. 2003;89:787-93. https://doi.org/10.1079/ BJN2003842

23. AOAC [Association of Official Analytical Chemists] International. Official methods of analysis of AOAC International. 17th ed. Gaithersburg, MD: AOAC International; 2000.

24. Sinnhuber RO, Yu TC. The 2-thiobarbituric acid reaction, an objective measure of the oxidative deterioration occurring in fats and oils. J Jpn Oil Chem Soc. 1977;26:259-67. https://doi. org/10.5650/jos1956.26.259

25. Sebranek JG, Bacus JN. Cured meat products without direct addition of nitrate or nitrite: what are the issues? Meat Sci 2007;77:136-47.https://doi.org/10.1016/j.meatsci.2007.03.025

26. Jokanović MR, Džinić NR, Tomović VM, Savatić SB, Tasić TA, Ikonić PM, et al. Effect of ground paprika and its oleoresin on marinated chicken breast meat quality. Acta Period Technol. 2011;42:55-62. https://doi.org/10.2298/APT1142055J

27. Kim GH, Chin KB. Physicochemical and textural properties of low-fat pork sausages with paprika powder. J Korean Soc Food Sci Nutr. 2018;47:917-25 https://doi.org/10.3746/ jkfn.2018.47.9.917

28. Revilla I, Quintana AMV. The effect of different paprika types on the ripening process and quality of dry sausages. Int J Food Sci Technol. 2005;40:411-7. https://doi.org/10.1111/j.13652621.2005.00944.x 
29. Tao NG, Gao YM, Liu YJ, Ge F. Carotenoids from the peel of Shatian pummelo (Citrus grandis Osbeck) and its antimicrobial activity. Am Eurasian J Agric Environ Sci. 2010;7:110-5.

30. De Oliveira TLC, de Araújo Soares R, Ramos EM, das Graças Cardoso M, Alves E, Piccoli RH. Antimicrobial activity of Satureja montana L. essential oil against Clostridium perfringens type a inoculated in mortadella-type sausages formulated with different levels of sodium nitrite. Int J Food Microbiol. 2011;144:546-55. https://doi.org/10.1016/j.ijfoodmicro.2010.11.022

31. Sperandio FF, Huang YY, Hamblin MR. Antimicrobial photodynamic therapy to kill gram-negative bacteria. Recent Pat Antiinfect Drug Discov. 2013;8:108-20. https://doi.org/10. 2174/1574891X113089990012

32. Herrmann SS. N-nitrosamines in processed meat products-analysis, occurrence, formation, mitigation and exposure [Ph.D. dissertation]. Lyngby, Denmark: National Food Institute, Technical University of Denmark; 2014.

33. Roberts TA. . The microbiological role of nitrite and nitrate. J Sci Food Agric. 1975;26:175560. https://doi.org/10.1002/jsfa.2740261118

34. Ahn HJ, Kim JH, Jo C, Lee CH, Byun MW. Reduction of carcinogenic N-nitrosamines and residual nitrite in model system sausage by irradiation. J Food Sci. 2002;67:1370-3. https://doi. org/10.1111/j.1365-2621.2002.tb10291.x

35. Kim HS, Seong PN, Chang MJ, Kim MH. Quality characteristics of cold storage pork patty by micro-encapsulation of natural additives. Food Eng Prog. 2013;17:355-61. http://doi. org/10.13050/foodengprog.2013.17.4.355 